\title{
PREDICTING THE RELATIONSHIP BETWEEN PERCEIVED INFLUENCE, BRAND ENGAGEMENT, BRAND EXPECTED VALUE AND INTENTION PURCHASE: AN EMPRICAL STUDY
}

\author{
Destian F Amaldi ${ }^{1)}$, Bella Sugita ${ }^{2)}$, Sabrina O. Sihombing ${ }^{* 3)}$ \\ Fakultas Ekonomi dan Bisnis, Universitas Pelita Harapan \\ *Corresponding Author : Email : sabrina.sihombing@uph.edu
}

\begin{abstract}
The purpose of this study is to predict the relationship between perceived influence, brand engagement, brand expected value, and intention to purchase. The data were gathered from online respondents. The research questionnaire was built from previous research and the research variables were measured by 5-point Likert scales. Before analyzing data for testing hypotheses, reliability and validity tests are performed first. Hypothesis testing is conducted by using structural equation modeling. The results show that there are four out of six hypotheses that are supported. This paper provides research discussion, limitation, and recommendation for future research.
\end{abstract}

Keywords: perceived influence, brand engagement, brand expected value, intention to purchase

\begin{abstract}
Abstrak
Tujuan dari penelitian ini adalah untuk memprediksi hubungan antara pengaruh yang dirasakan, keterlibatan merek, nilai yang diharapkan merek, dan niat untuk membeli. Data dikumpulkan dari responden online. Kuisioner penelitian dibangun dari penelitian sebelumnya dan variabel penelitian diukur dengan skala Likert 5 poin. Sebelum menganalisis data untuk menguji hipotesis, uji reliabilitas dan validitas dilakukan terlebih dahulu. Pengujian hipotesis dilakukan dengan menggunakan pemodelan persamaan struktural. Hasil penelitian menunjukkan bahwa ada empat dari enam hipotesis yang didukung. Makalah ini memberikan diskusi penelitian, batasan, dan rekomendasi untuk penelitian masa depan.
\end{abstract}

Kata kunci: pengaruh yang dirasakan, keterlibatan merek, nilai harapan merek, niat untuk membeli

\section{INTRODUCTION}

The development of internet technology is driving changes both directly and indirectly to business (Kotler et al., 2017). In particular, these changes affect mainly in businesses such as marketing systems, communications and how to deal. This is because internet technology offers various advantages. The existence of technological advances, especially the internet makes the limitations of time, distance and costs can be overcome. Businesses are starting to expand their business from offline to online to make it easier for consumers. E-commerce is a business transaction carried out through electronic networks such as the internet (Bhasker, 2009). Moreover, companies that have internet networks can create e-commerce platforms. E-commerce can connect with consumers through the web which operates 24 hours. E-commerce makes it easy for companies to market their products quickly and easily. 
One company that utilizes e-commerce in Indonesia is the travel industry. The support of natural resources makes tourists come to Indonesia. This is evident from the increase in tourist arrivals to Indonesia in 2019, growing 4.01\% from last year. Indonesia is also the 4th country in ASEAN with the highest number of tourists after Singapore. With e-commerce becoming an opportunity for the travel industry in Indonesia. The contribution of e-commerce to the travel industry reaches $60 \%$ of total revenue. Ecommerce helps companies and consumers not to meet. They can make contact or and interact via the internet or telephone. E-commerce makes it easy for consumers around the world to purchase hotel tickets and airplane tickets online without being limited by time. Thus, the existence of e-commerce makes it easy for the travel industry to make buying and selling transactions (Subarkah, 2018).

One travel industry that utilizes e-commerce is Tiket.com. Tiket.com is one of the online platforms engaged in booking plane tickets, trains and hotels. Tiket.com was established to meet the needs of the community dynamically with high mobility, thus requiring ease and speed in conducting transactions. Tiket.com offers ticket sales online and direct payments are also made via e-commerce without having to meet in person.

The Alvara Research Institute notes that Traveloka's trademark is the most popular ticket and hotel booking platform for 1,204 millennial respondents born in 1981-1997. Traveloka emerged as the application most often used by 79 percent of respondents. Then the second position was followed by Tiket.com with a percentage of 8.9 percent. The difference between the first and second positions is a big gap (Thomas, 2019). To increase online ticket sales and make consumers more familiar with Tiket.com, companies must implement a marketing strategy. One of them the company can introduce its business through social media through influencers.

One of the things that drives successful marketing is to use influencer marketing (Hariyanti \& Wirapraja, 2018). Influencer marketing is marketing by appointing people or figures who are considered to have influence in the community, especially the target consumers. Influencers that are intended can be promotional media of the brand. The use of influencers plays as a buyer to market a product or service. Influencers can upload photos, videos and explain products and services from Tiket.com. Promoting through Instagam feeds, paid promoting and providing contact links so he can introduce to followers about Tiket.com services. There are positive reviews from influencers and representing Tiket.com services encourage interest in using these services. Therefore, the presence of influencers can increase interest in the use of a service (Sugiharto \& Ramadhana, 2018)

There are many research on intention to buy in an online context (e.g. Hermanda et al., 2019; Liempepas et al., 2019; Ranadive, 2015; Shierley \& Sihombing, 2015; Huang \& $\mathrm{Su}, 2011$; Ling et al., 2010). The brand is one of the significant predictors of intention to buy. This includes brand image, brand branding, brand awareness, and other brand variables (e.g., Hermanda et al., 2019; Fikri et al., 2018; Wiranti \& Nuhraga, 2017; Vivek et al., 2912). However, studies rarely examine perceived influence as predictor of intention to buy. Therefore, this research fills the gap by empirically testing a model which was developed by Jiménez-Castillo and Sánchez-Fernández (2019) that integrates the variables of perceived influence, brand expectation value, and brand involvement in predicting purchase intentions.

Companies apply social media as a strategic resource for advertising their brands and products and for building strong relationships with their consumers (Shiau et al., 2018). This fact has attracted the attention of researchers and practitioners who are concerned 
with brand issues and social media platforms. Specifically,studies have examined how companies can utilize social media to develop branding and marketing strategies (Ananda et al., 2016; Hudson, Huang, Roth, \& Madden, 2016; Childers et al., 2018). In relating with consumer behavior, individuals develop their consumer attitudes and behavior patterns in part as a result of their interactions and learning from external parties such as friends, peers, or the mass media. This interaction, like key aspects of the communication process, is usually associated with social functions to build relationships with the speaker and ultimately can lead to greater involvement of the message content.

In addition, when a message comes from a reference group, individuals use the brand associated with the message as a contribution to form their self-concept, establish a connection or link with it. The connection between influencers and followers is possible through the attribution process, identification that will be generated with a message that contains meaning. Thus, followers are influenced and will follow leaders (influencers) to show greater involvement towards the recommended brand, by integrating them into their self-concepts so that they contribute to their personal development identity. Research by Jiménez-Castillo and Sánchez-Fernández (2019), Hermanda et al (2019), Abidin (2015), Crespo et al. (2015) show that perceived influence have a positive effect on intention to purchase. Then the hypothesis for this research is:

$\mathrm{H}_{1}$ : There is a significant and positive relationship between perceive influence and intention to purchase

According to Hollebeek (2011), brand engagement is the level of individuals associated with brands and thoughts that have a dependency on the context that is characterized by specific stages namely attitudes, emotional, cognitive that are directly related to a brand. Brand involvement signifies an emotional commitment to a brand. Brand involvement is important for building and help to strengthen brands (Indrianti, 2016). Social media has given new meaning to word of mouth marketing and the ability for consumers to interact with brands at new levels and build relationships in new ways. Brand involvement is in line with the involvement of customers and the customers involved translate to increase revenue, profitability, and market share.

Research shows that opinions, decisions, and other individual behaviors can help in shaping expectations felt by consumers. Previous research has shown that the influence exerted by individuals on information sources has a positive and significant influence on the formation of perceived value for a product or service. Therefore, e-WOM can have an impact on all customers the perceived value of the product. Therefore, one can predict that the influence exerted by digital influencers contribute to the formation of brand value. Information delivered by influencers about a product is considered to be of high value by followers. Previous research has shown that the positive relationship between perceive influence and brand engagment (e.g., Hermanda et al, 2019; Jiménez-Castillo \& SánchezFernández, 2019; Al-Debe, 2015; Kimhan, 2009; Allen, 2008). Then the hypothesis for this research is

$\mathrm{H}_{2}$ : There is a significant and positiverelationship between perceived influence and brand engagement

Research shows that the influence of social networking from outside parties has a significant impact on consumer behavior. That purchasing decisions benefit from influential individual opinions disseminated through eWOM, which are considered quality and with greater credibility, and even generate buying interest. Even research corroborates leaders who influence opinions about the intended use or purchase. Thus, the greater the 
power of influencers, the greater the individual's intention to buy the recommended brand. This is because information will be considered as a consistent source of information. Research by Jiménez-Castillo and Sánchez-Fernández (2019), Kimhan (2009), Bao and Chang (2014), Wang and Lin (2011) and Wang and Yu (2017) state that perceived influence have a positive influence on brand expectation value. Then the hypothesis for this research is

$\mathrm{H}_{3}$ : There is a significant and positive relationship between perceived influence and brand expected value

According to Hollebeek (2011), brand engagement is the level of individuals associated with brands and thoughts that have a dependency on the context that is characterized by specific stages namely attitudes, emotional, cognitive that are directly related to a brand. Brand involvement signifies an emotional commitment to a brand. This is more than brand awareness; it is loyalty and word of mouth marketing. Brand involvement is important both internally and externally. Building brands internally and gaining employee involvement with brands helps to strengthen and build brands that ultimately enhance brands for consumers (Indrianti, 2016). Social media has given new meaning to word of mouth marketing and the ability for consumers to interact with brands at new levels and build relationships in new ways. Brand involvement is in line with the involvement of customers and the customers involved translate to increase revenue, profitability, and market share. Research by Hollebeek (2012), France et al. (2016), Youssef et al. (2018), Jimenez-Castillo and Sánchez-Fernández (2019) and Leckie (2018) stated that nand engagement influences brand expected value positively. Then the hypothesis for this research is

The hypothesis for this research is

$\mathrm{H}_{4}$ : There is a significant and positive relationship between brand engagement and brand expected value

Involvement is a driver of consumer behavior indicating that one consequence of brand involvement is behavioral interest. As such, some research has argued that people who are characterized by being excited and becoming deeply connected with the brand develop affection and loyalty for it. Thus, emotional commitment and connections that are highly involved individuals will influence their behavioral intentions towards the brand. Previous studies have empirically validated the influence of brand involvement regarding concepts related to behavioral intentions, such as intention to use brand behavioral interests for loyalty. Especially Sinta et al. (2009) concluded that a higher level of brand involvement in self-concept was associated with purchase intentions. So the involvement of a follower's brand develops from the expected persuasive impact of an influencer (following the recommendations given by an influencer) will have an impact in terms of a greater intention to buy that brand. Previous research show the significant relationship between brand engagement and intention to purchase (Hollebeek, 2012; Vivek et al., 2012; Leckie, 2018; Jimenez-Castillo \& Sánchez-Fernández, 2019; Youssef et al., 2018). Thus, the research hypothesis can be stated a s follows:

$\mathrm{H}_{5}$ : There is significant and positive relationship between brand engagement and intention to purchase.

Brand expected value is defined as a term, sign, symbol, design or combination of all of these that is intended to identify a product or service from a person or group of sellers, which distinguishes the product / service from other products, especially rival products (Bao \& Chang, 2014; Hsu , Lin, \& Chiang, 2013). There is an assumption about a brand 
that is reflected by consumers who hold on to consumers' memories. Specifically, the way people think about a brand in the abstract in their thinking, even when they think about it, they don't deal directly with the product. Building a positive brand image can be achieved with a strong marketing program for the product, which is unique and has highlighted advantages, which distinguishes it with other products (Uzunoğlu \& Kip, 2014) .. A good combination of supporting elements can create a strong brand value that is reflected to consumers. This value is very beneficial for producers or companies.

Previous research show that there is a significant relationship between brand expected value and intention to purchase (e.g., Uzunoğlu \& Kip, 2014; Mencarelli \& Lombart, 2017; Chen et al., 2014; Jiménez-Castillo \& Sánchez-Fernández, 2019; Bonsón Ponte et al., 2015). Thus, the hypothesis for this research is

$\mathrm{H}_{6}$ : There is a significant and positive relationship between brand expected value and intention to purchase

Figure 1. Research Model

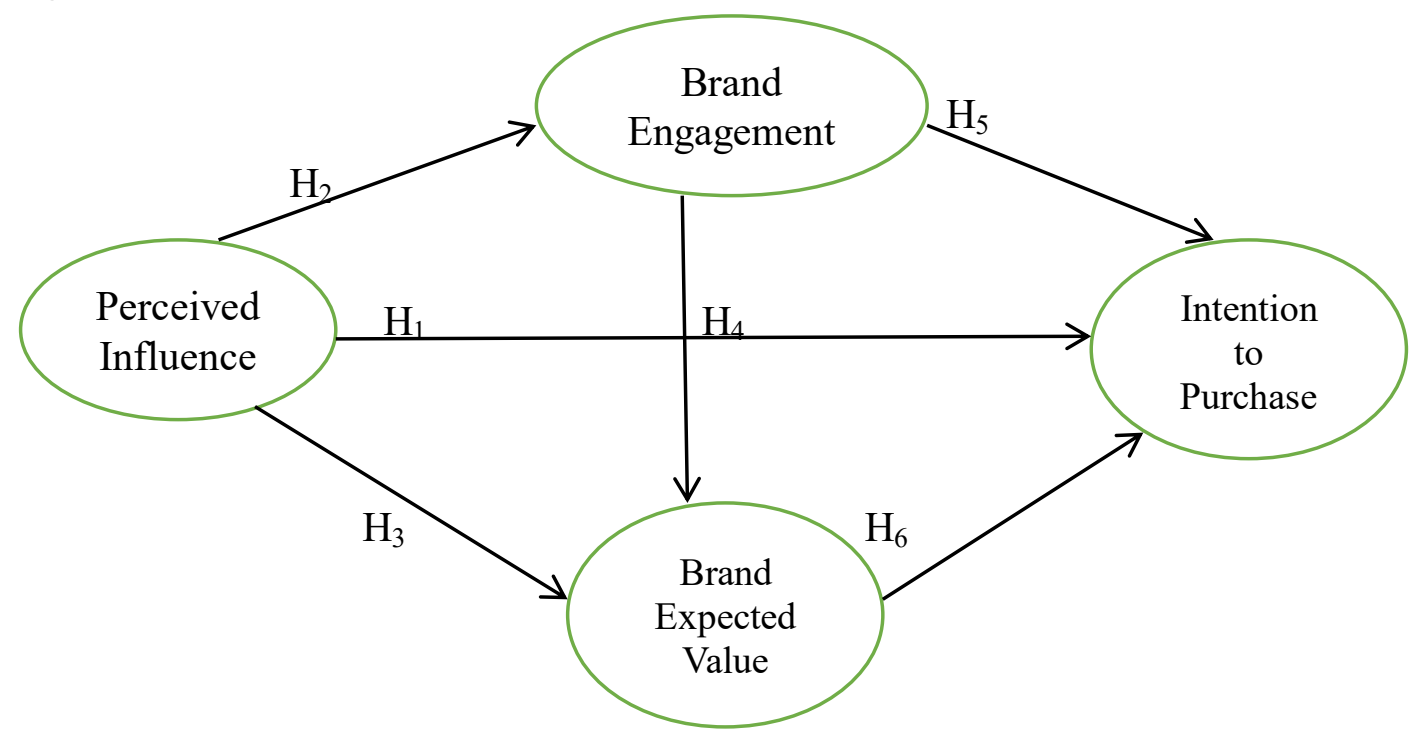

Source : Jiménez-Castillo \& Sánchez-Fernández (2019)

\section{METHODS}

This research is a quantitative research. Specifically, this study aims to examine the research model through hypothesis testing. The research questionnaire was built from previous research (ie, Jiménez-Castillo \& Sánchez-Fernández, 2019). The research variables were measured by 5 -point Likert scales (from 1 "strongly disagree" to 5 "strongly agree"). Questionnaires are distributed online considering the distribution of questionnaires online is to get data faster without being limited by time and geography. This study used a purposive sampling design with the main criteria is respondents having used Tiket.com. The number of samples in this study is 121 respondents. Before analyzing data for testing hypotheses, reliability and validity tests are performed first. Hypothesis testing is conducted by using structural equation modeling.

\section{RESULTS AND DISCUSSION}

Of the 121 questionnaires received, there were 112 completed questionnaires. Specifically, the respondents who were sampled in this study were 51 people $(45.5 \%)$ who 
were male and 61 people $(54.5 \%)$ were female. Respondents who were sampled in this study were 26 people $(23.2 \%)$ aged $15-20$ years, 57 people $(50.9 \%)$ aged $21-25$ years, 25 people $(22.3 \%)$ aged $26-30$ years and 4 people (3.6\%) aged $31-35$ years.

Usable responses were received from 112 respondents. These data are then analyzed for the reliability and validity test before testing the hypothesis. Table 1 shows the results of reliability and validity tests. The results show that the indicators of this study are reliable and valid.

Table 2. Relibility and Validity Tests

\begin{tabular}{|c|c|c|c|c|c|}
\hline \multirow[b]{2}{*}{$\begin{array}{l}\text { Variable and } \\
\text { Indicators }\end{array}$} & \multicolumn{3}{|c|}{ Reliability } & \multicolumn{2}{|c|}{ Validity } \\
\hline & $\begin{array}{l}\text { Corrected } \\
\text { Item-Total } \\
\text { Correlation }\end{array}$ & $\begin{array}{c}\text { Cronbach's } \\
\text { Alpha }\end{array}$ & $\begin{array}{l}\text { Composite } \\
\text { Reliability }\end{array}$ & $\begin{array}{c}\text { AVE } \\
(>0.5)\end{array}$ & $\begin{array}{c}\text { Outer Loading } \\
(>\mathbf{0 . 7})\end{array}$ \\
\hline \multicolumn{6}{|l|}{ Perceived Influence } \\
\hline $\begin{array}{l}\text { My perception can } \\
\text { change when I } \\
\text { receive information } \\
\text { from influencers that } \\
\text { I follow }\end{array}$ & 0,477 & \multirow{3}{*}{0,913} & \multirow{3}{*}{0,935} & \multirow{3}{*}{0,741} & 0,812 \\
\hline $\begin{array}{l}\text { I respect the opinion } \\
\text { of influencers that I } \\
\text { follow as if they are } \\
\text { someone close to me }\end{array}$ & 0,443 & & & & 0,840 \\
\hline $\begin{array}{l}\text { The influencers that I } \\
\text { participated in } \\
\text { recommended the } \\
\text { Tiket.com service to } \\
\text { me }\end{array}$ & 0,738 & & & & 0,847 \\
\hline \multicolumn{6}{|l|}{ Brand Engagement } \\
\hline $\begin{array}{l}\text { I have a match with } \\
\text { TIket.com }\end{array}$ & 0,781 & \multirow{3}{*}{0,908} & \multirow{3}{*}{0,942} & \multirow{3}{*}{0,844} & 0,916 \\
\hline $\begin{array}{l}\text { A part of me is } \\
\text { defined by Tiket.com }\end{array}$ & 0,73 & & & & 0,907 \\
\hline $\begin{array}{l}\text { There is a connection } \\
\text { between Tiket.com } \\
\text { and my needs }\end{array}$ & 0,789 & & & & 0,934 \\
\hline \multicolumn{6}{|l|}{ Brand Expected Value } \\
\hline $\begin{array}{l}\text { I am sure Tiket.com } \\
\text { has good quality } \\
\text { standards }\end{array}$ & 0,735 & \multirow{4}{*}{0,921} & \multirow{4}{*}{0.941} & \multirow{4}{*}{0,762} & 0,900 \\
\hline $\begin{array}{l}\text { In my opinion, } \\
\text { services from } \\
\text { Tiket.com are well } \\
\text { provided }\end{array}$ & 0,729 & & & & 0,917 \\
\hline $\begin{array}{l}\text { The services } \\
\text { provided by } \\
\text { Tiket.com are } \\
\text { interesting to me }\end{array}$ & 0,74 & & & & 0,906 \\
\hline $\begin{array}{l}\text { I recommend } \\
\text { Tiket.com positively }\end{array}$ & 0,484 & & & & 0,744 \\
\hline
\end{tabular}


Jurnal Manajemen Terapan dan Keuangan (Mankeu) Vol. 10 No. 01, April 2021

P-ISSN: 2252-8636, E-ISSN: 2685-9424

\begin{tabular}{|c|c|c|c|c|c|}
\hline $\begin{array}{l}\text { In my opinion, } \\
\text { Tiket.com is useful } \\
\text { for me }\end{array}$ & 0,724 & & & & 0,885 \\
\hline \multicolumn{6}{|l|}{ Purchase Intention } \\
\hline $\begin{array}{l}\text { I will continue to use } \\
\text { Tiket.com }\end{array}$ & 0,704 & \multirow{5}{*}{0,784} & \multirow{5}{*}{0.872} & \multirow{5}{*}{0,694} & 0,862 \\
\hline $\begin{array}{l}\text { I will follow the } \\
\text { Tiket.com service } \\
\text { update }\end{array}$ & 0,66 & & & & 0,901 \\
\hline $\begin{array}{l}\text { For the future, I will } \\
\text { use Tiket.com } \\
\text { services }\end{array}$ & 0,655 & & & & 0,884 \\
\hline $\begin{array}{l}\text { I am interested in } \\
\text { using Tiket.com }\end{array}$ & 0,559 & & & & 0,844 \\
\hline $\begin{array}{l}\text { I will not use any } \\
\text { other brand besides } \\
\text { Tiket.com }\end{array}$ & 0,506 & & & & 0,812 \\
\hline
\end{tabular}

Hypothesis testing is conducted by using structural equation modeling. The results in Table 2 show that there are two hypotheses that are not supported since the P-Value of those two hypotheses were above 0.005 and T-value above 1.96 (Table 2 and 3).

Table 2. Hypotheses Testing

\begin{tabular}{|l|c|c|c|c|}
\hline \multicolumn{1}{|c|}{ Hypothesis } & Path Value & T-Value & P-Value & Conclusion \\
\hline $\begin{array}{l}\text { There is significant } \\
\text { relationship between } \\
\text { perceived influence } \\
\text { and intention to } \\
\text { purchase }\end{array}$ & 0,180 & 1,690 & 0,092 & Not Supported \\
\hline $\begin{array}{l}\text { There is significant } \\
\text { relationship between } \\
\text { perceived influence } \\
\text { and brand } \\
\text { engagement }\end{array}$ & 0,775 & 20,415 & 0,000 & Supported \\
\hline $\begin{array}{l}\text { There is significant } \\
\text { relationship between } \\
\text { perceived influence } \\
\text { and brand expected } \\
\text { value }\end{array}$ & 0,260 & 3,362 & 0,001 & Supported \\
\hline $\begin{array}{l}\text { There is significant } \\
\text { relationship between } \\
\text { brand engagement } \\
\text { and brand expected } \\
\text { value }\end{array}$ & 0,615 & 7,516 & 0,000 & Supported \\
\hline $\begin{array}{l}\text { There is significant } \\
\text { relationship between } \\
\text { brand engagement } \\
\text { and intention to }\end{array}$ & 0,510 & 5,224 & 0,000 & Supported \\
\hline
\end{tabular}




\begin{tabular}{|l|l|l|l|l|}
\hline purchase & & & \\
\hline $\begin{array}{l}\text { There is significant } \\
\text { relationship between } \\
\text { brand expected value } \\
\text { and intention to } \\
\text { purchase }\end{array}$ & 0,152 & 1,421 & 0,156 & Not Supported \\
\hline
\end{tabular}

Table 3. $\mathrm{R}^{2}$ Values for Actual Test

\begin{tabular}{|l|c|c|}
\hline \multicolumn{1}{|c|}{ Variables } & R Square & R Square Adjusted \\
\hline Perceived Influence & 0,597 & 0,593 \\
\hline Brand Engagement & 0,692 & 0,685 \\
\hline Brand Expected Value & 0,624 & 0,612 \\
\hline
\end{tabular}

The results showed that the perceived influence did not have a significant and positive relationship with the intention to purchase. This is different from the results of previous studies and also from the underlying theoretical framework. The reason can be given that not everything in the lives of consumers is always influenced by the recommendations of others. For example, there are consumers who are loyal to the the specific ticket sales online, for example Traveloka, because they don't want to mess around with other administrative issues. Although Tiket.com provides many promotions, it still takes time for consumers to trust Tiket.com compared to Traveloka, which is far more experienced and has high brand awareness.

The results also showed that the brand expected value did not have a significant and positive relationship with intention to buy. The reasons for not supporting this hypothesis are as follows. Tiket.com brand is not well-known compared to its main competitor, Traveloka. So even though the value that can be given by Tiket.com is the lower price due to promotion, consumers do not yet understand the value proposition offered by Tiket.com. In other words, consumers need time to understand the value proposition offered by Tiket.com.

\section{CONCLUSION}

This research aims to examine the relationship between perceived influence, brand engagement, brand expected value, and intention to purchase. The results showed that two hypotheses were rejected. Those hypotheses are the relationship between perceived influence and intention to purchase and the relationship between brand expected value and intention to purchase. This research is inseparable from its limitations. First, this study is a cross sectional study that only describes respondents at one time. Then, this study uses a non-probability sample design that gives the consequence that the results of this study cannot be generalized in the same or different contexts. For this limitation, further research can re-examine the research model using different respondents or research objects. The research results will then enrich the understanding of this research model.

\section{References}

Abidin, C. (2015). Communicative intimacies: Influencers and perceived interconnectedness. Ada: A Journal of Gender, New Media, and Technology, 8(1)https:// adanewmedia.org/2015/11/issue8-abidin/.

Alalwan, A. A., Dwivedi, Y. K., Rana, N. P., \& Simintiras, A. C. (2016). Jordanian 
con- sumers' adoption of telebanking: Influence of perceived usefulness, trust and self- efficacy. INTERNATIONAL JOURNAL of BANK MARKETING, 34(5), 690-709.

Alalwan, A. A., Rana, N. P., Dwivedi, Y. K., \& Algharabat, R. (2017). Social media in marketing: A review and analysis of the existing literature. TELEMATICS AND INFORMATICS, 34(7), 1177-1190.

Al-Debei, M. M., Akroush, M. N., \& Ashouri, M. I. (2015). Consumer attitudes towards online shopping: The effects of trust, perceived benefits, and perceived web quality. Internet Research, 25(5), 707-733.

Ananda, A. S., Hernández-García, Á., \& Lamberti, L. (2016). N-REL: A comprehensive framework of social media marketing strategic actions for marketing organizations. JOURNAL of INNOVATION \& Knowledge, 1(3), 170-180

Bangga, R. Dwi. (2016). Uji Validitas Dan Reliabilitas Instrumen B-IPQ (Brief Illness Oerception Questionnare) Versi Indonesia Pada Pasien Diabetes Melitus Di RSUD Sultan Syarif Mohamad Alkadrie Kota Pontianak. Skripsi Program Studi Farmasi Fakultas Kedokteran Universitas Tanjungpura Pontianak, 1-8. Http://Statistikapendidikan.Com/Wp-Content/Uploads/2013/05/Uji-Validitas-DanReliabilitas.Gilang-AM1.Pdf

Bao, T., \& Chang, T. L. S. (2014). Finding Disseminators Via Electronic Word Of Mouth Message For Effective Marketing Communications. Decision Support Systems, 67, 21-29.

Bhasker, B. (2009). Electronic Commerce Framework, Technologies Applications. New Delhi: Tata McGraw-Hill Publishing Company Limited.

Bonson, Ponte Enrique, Elena Carvajal-Trujillo, Tomas Escobar-Rodríguez, Influence Of Trust And Perceived Value On The Intention To Purchase Travel Online: Integrating The Effects Of Assurance On Trust Antecedents , Tourism Management Volume 47, April 2015, Pages 286-302

Casaló, L. V., Flavián, C., \& Ibáñez-Sánchez, S. (2018). Influencers On Instagram: Antecedents And Consequences Of Opinion Leadership. JOURNAL Of Business RESEARCH In Press.

Cheng, L. (2012). Critical Success Factors (Csfs) For TQM Implementation: Current Status And Challenges In Libyan Manufacturing Companies. GSTF Journal On Business Review, 2(1), 71-79. Https://Doi.Org/10.5176/2010-4804

Childers, C. C., Lemon, L. L., \& Hoy, M. G. (2018). \#Sponsored \#Ad: Agency Perspective On Influencer Marketing Campaigns. JOURNAL Of Current Issues \& RESEARCH In Advertising, 1-17.

Crespo, A.H., Gutiérrez, H.S.M., Mogollón, J.M.M. (2015). Perceived influence on behavior of user-generated content on social network sites: An empirical application in the hotel sector. Revista Española de Investigación de Marketing ESIC, 9(1), 1223

Dwivedi, A. (2015). A Higher-Order Model Of Consumer Brand Engagement And Its Impact On Loyalty Intentions. JOURNAL Of RETAILING AND Consumer Services, 24, 100-109.

Dwivedi, Y. K., Kapoor, K. K., \& Chen, H. (2015). Social Media Marketing And Advertising. The MARKETING Review, 15(3), 289-309.

Fikri, I., Yasri, Y., \& Abror, A. (2018). The Impact Of Brand Experience And Brand Trust On Brand Engagement: The Mediating Effect Of Brand Satisfaction N. Advances In Economics, Business And Management Research, 57(January). Https://Doi.Org/10.2991/Piceeba-18.2018.43 
France, C., Merrilees, B. \& Miller, D. An Integrated Model Of Customer-Brand Engagement: Drivers And Consequences. J Brand Manag 23, 119-136 (2016). Https://Doi.Org/10.1057/Bm.2016.4

Gruen, T. W., Osmonbekov, T., \& Czaplewski, A. J. (2006). Ewom: The Impact Of Cus- Tomer-To-Customer Online Know-How Exchange On Customer Value And Loyalty. JOURNAL Of Business RESEARCH, 59(4), 449-456

Hajli, N., Shanmugam, M., Papagiannidis, S., Zahay, D., \& Richard, M. O. (2017). Branding Co-Creation With Members Of Online Brand Communities. JOURNAL Of Business RESEARCH, 70, 136-144

Hariyanti, N. T., \& Wirapraja, A. (2018). Pengaruh Influencer Marketing Sebagai Strategi Pemasaran Digital Era Moderen (Sebuah Studi Literatur). Jurnal Eksekutif, 15(1), 133-146.

Hermanda, A., Sumarwan, U., \& Tinaprillia, N. (2019). The Effect Of Social Media Influencer On Brand Image, Self-Concept, And Purchase Intention. Journal Of Consumer Sciences, 4(2), 76-89. Https://Doi.Org/10.29244/Jcs.4.2.76-89

Huang X. \& Su D. (2011). Research on Online Shopping Intention of Undergraduate Consumer in China-Based on the Theory of Planned Behavior International Business Research, 4. 86-92

Hudson, S., Huang, L., Roth, M. S., \& Madden, T. J. (2016). The Influence Of Social Media Interactions On Consumer-Brand Relationships: A Three-Country Study Of Brand PercCeptions And Marketing Behaviors. INTERNATIONAL JOURNAL Of RESEARCH In MARKETING, 33(1), 27-41.

Indrianti, L. (2016). Pembentukan Brand Engagement Pada Pelanggan Telkomsel Dan Indosat Melalui Media Social Facebook, Twitter Dan Instagram. Https://Doi.Org/10.1057/9780230579507

Jiménez-Castillo, D., \& Sánchez-Fernández, R. (2019). The Role Of Digital Influencers In Brand Recommendation: Examining Their Impact On Engagement, Expected Value And Purchase Intention. International Journal Of Information Management, 49(February), 366-376. Https://Doi.Org/10.1016/J.Ijinfomgt.2019.07.009

Kotler, P., Kartajaya, H.. \& Setiawan, L. (2017). Marketing 4.0: Moving From Traditional to Digital. NJ: John Wiley \& Sons, Inc.

Jogiyanto. (2017). Konsep Dasar Sistem Informasi. Konsep Dasar Sistem Informasi.

Liempepas, I., Meichael, \& Sihombing, S. O., (2019). Analisis Faktor - Faktor Yang Mempengaruhi Niat Penggunaan Berkelanjutan: Studi Empiris Pada Mobile Banking BCA. JRMSI - Jurnal Riset Manajemen Sains Indonesia, 10(2), 306 - 336. Retrieved from http://journal.unj.ac.id/unj/index.php/jrmsi/article/view/11684

Ling K.C., Chai L.T. \& Piew T.H. (2010). The Effects of Shopping Orientations, Online Trust and Prior Online Purchase Experience Toward Customers' Online Purchase Intention, International Business Research, 3, 63-76

Marbach, J., Lages, C. R., \& Nunan, D. (2016). Who Are You And What Do You Value? Investigating The Role Of Personality Traits And Customer-Perceived Value In Online Customer Engagement. JournaL Of MARKETing Management, 32(5-6), 502-525

Marsella, D. (2017). Pengaruh Kepercayaan, Keuntungan Yang Dirasakan, Dan Kualitas Web Pada Sikap Konsumen Atas Pembelian Tiket Pesawat Secara Online. Universitas Lampung.

Pradipta, B. (2014). Pengaruh Citra Merek, Keterlibatan Produk, Dan Pengetahuan Produk Terhadap Niat Konsumen Membeli Minuman Isotonik Pocari Sweat Di 
Surabaya. Sekolah Tinggi Ilmu Ekonomi Perbanas.

Priyatno, D. (2010). Teknik mudah dan cepat melakukan analisis data penelitian dengan SPSS dan tanya jawab ujian pendadaran. Yogyakarta: Gava Media.

Rahmidani, R. (2015). Penggunaan E-Commerce Dalam Bisnis Sebagai Sumber Keunggulan Bersaing Perusahaan. Penggunaan E-Commerce Dalam Bisnis Sebagai Sumber Keunggulan Bersaing Perusahaan, c, 345-352. http://fe.unp.ac.id/sites/default/files/unggahan/26. Rose Rahmidani (hal 344352)_0.pdf

Ranadive A. (2015). An Empirical Study on the Online Grocery Shopping Intentions of Consumers in Vadodara City International Journal of Management and Social Sciences Research, 4, 8-14

Riska Riana Paramita, L. P., Suardana, I. W., \& Sendra, I. M. (2018). Efektivitas Promosi Tiket.Com Terhadap Keputusan Wisatawan Domestik Dalam Pembelian Tiket $\begin{array}{llllll}\text { Pesawat Menuju Bali. Jurnal } & \text { IPTA, }\end{array}$ https://doi.org/10.24843/ipta.2018.v06.i02.p04

Shierley, L. \& Sihombing, S.O. (2015). Predciting Online Purchase Intention; an Empirical Study. Proceeding of Management Dynamic Conferences, 7 October. Retrieved from: http://citeseerx.ist.psu.edu/viewdoc/download?doi=10.1.1.735.9923\&rep=rep1\&type $=\mathrm{pdf}$

Subarkah, A. R. (2018). Potensi dan Prospek Wisata Halal Dalam Meningkatkan Ekonomi Daerah (Studi Kasus: Nusa Tenggara Barat). Jurnal Sospol, 4(2), 49-72.

Sugiharto, S. A., \& Ramadhana, M. R. (2018). Pengaruh Kredibilitas Influencer Terhadap Sikap Pada Merek (Studi pada Mahasiswa Fakultas Komunikasi dan Bisnis Universitas Telkom). Ilmu Politik Dan Komunikasi, VIII(2).

Sundjaja, A. M., Ernawati, E., Holil, \& Kharen, P. (2016). Penerapan Strategi EMarketing untuk Internasionalisasi Jurnal Binus : Kasus Binus Business Review.

Suyanto, M. (2003). Top, Strategi Periklanan pada E-Commerce Perusahaan Dunia. PT. Elex Media Komputindo Kelompok Gramedia, Jakarta. https://doi.org/10.1371/journal.pmed.1002471

Swastha, Basu, I. (2014). Manajemen Pemasaran Modern. In Liberty, Yogyakarta. https://doi.org/10.1017/CBO9781107415324.004

Thomas, V.F. (2019). Traveloka Lebih Banyak Digunakan Milenial Ketimbang Tiket.com. Retrieved from https://irto.id/edXE

Tjiptono, F., \& Chandra, G. (2018). Manajemen Kualitas Jasa. Yogyakarta. ANDI. https://doi.org/10.12691/jbms-4-4-1

Vivek, S. D., Beatty, S. E., \& Morgan, R. M. (2012). Customer engagement: Exploring customer relationships beyond purchase. Journal of Marketing Theory and Practice, 20(2), 122-146. https://doi.org/10.2753/MTP1069-6679200201

Wiranti, M. W., \& Nugraha, H. S. (2017). Analisis Strategi Customer Engagement terhadap Loyalitas pada PT. Nasmoco Magelang. Ilmu Administrasi Bisnis, 6(1), 322-331.

Youssef, Y. M. A., Johnston, W. J., AbdelHamid, T. A., Dakrory, M. I., \& Seddick, M. G. S. (2018). A customer engagement framework for a B2B context. JOURNAL of BusinesS AND INDUSTRIAL MARKETING, 33(1), 145-152 